\title{
THE
}

8-1-2002

\section{Evidence of Inter- and Intra-Molecular Crosslinking of Tyrosine Residues of Calmodulin Induced by Photo-Activation of Ruthenium(II)}

\author{
Oleg A. Andreev \\ University of Rhode Island, andreev@uri.edu \\ Yana K. Reshetnyak \\ University of Rhode Island, reshetnyak@uri.edu \\ Ronald H. Goldfarb
}

Follow this and additional works at: https://digitalcommons.uri.edu/phys_facpubs

Terms of Use

All rights reserved under copyright.

\section{Citation/Publisher Attribution}

Andreev, O. A., Reshetnyak, Y. K., \& Goldfarb, R. H. (2002). Evidence of inter- and intra-molecular crosslinking of tyrosine residues of calmodulin induced by photo-activation of ruthenium(II). Photochem Photobiol Sci, 1(10), 834-836. doi: 10.1039/B201474B

Available at: http://dx.doi.org/10.1039/B201474B

This Article is brought to you for free and open access by the Physics at DigitalCommons@URI. It has been accepted for inclusion in Physics Faculty Publications by an authorized administrator of DigitalCommons@URI. For more information, please contact digitalcommons-group@uri.edu. 


\title{
Evidence of inter- and intra-molecular crosslinking of tyrosine residues of calmodulin induced by photo-activation of ruthenium(II)
}

\author{
Oleg A. Andreev, * Yana K. Reshetnyak and Ronald H. Goldfarb \\ Department of Molecular Biology and Immunology, Institute for Cancer Research, \\ University of North Texas Health Science Center at Fort Worth, 3500 Camp Bowie Blvd., \\ Fort Worth, TX 7610,USA. E-mail: oandreev@hsc.unt.edu; Fax: + (1)817 7352118; \\ Tel: + (1) 8177352127
}

Received 11th February 2002, Accepted 5th July 2002

First published as an Advance Article on the web 1st August 2002

Tris(2,2'-bipyridyl)ruthenium(II) upon illumination with light at a wavelength of $450 \mathrm{~nm}$ in the presence of an electron acceptor induces dityrosine crosslinking in proteins.

\section{Introduction}

The ability of metal-ligand complexes (MLC) to participate in electron-transfer reactions finds numerous applications in physics, biophysics, electrochemistry, biology and medicine. ${ }^{1-4}$ One of these MLCs, tris(2,2'-bipyridyl)ruthenium(II), or Ru(II), has unique photophysical features. The absorption of light is associated with the transfer of an electron from the ruthenium atom to one of the three bipyridyl groups, and in the excited state the electron can be easily donated to other molecules (electron acceptors). The loss of an electron converts the chemically neutral $\mathrm{Ru}(\mathrm{II})$ into $\mathrm{Ru}(\mathrm{III})$, which is a strong oxidant able to oxidize the other molecules and, particularly, amino acid residues such as tyrosine and tryptophan in peptides. ${ }^{5}$ Recently, it has been reported that, upon illumination with light at a wavelength of $450 \mathrm{~nm}, \mathrm{Ru}$ (II) could catalyze the crosslinking of proteins. ${ }^{6,7}$ One of the possible mechanisms of protein crosslinking could be the formation of a covalent bond between two tyrosine residues (dityrosine formation). To examine this hypothesis we performed the crosslinking of calmodulin induced by photoactivation of $\mathrm{Ru}(\mathrm{II})$. Calmodulin has been selected for these experiments because it has only two tyrosine and no tryptophan residues, and dityrosine formation can be monitored by the appearance of specific fluorescence with a maximum at 410 nm. ${ }^{8,9}$ In the present work we have demonstrated for the first time that $\mathrm{Ru}(\mathrm{II})$ can catalyze dityrosine crosslinking in proteins. Using a CCD camera and interference filters we were able to detect dityrosine fluorescence directly from the polyacrylamide gel.

\section{Materials and methods}

\section{Reagents}

Tris(2,2'-bipyridyl)dichlororuthenium(II) hexahydrate, ammonium persulfate (APS), sodium azide $\left(\mathrm{NaN}_{3}\right)$, superoxide dismutase from bovine erythrocytes (SOD) and bovine brain calmodulin were purchased from Sigma (St. Louis, MO). Ethyl alcohol (spectrophotometric grade) was from Aldrich (Milwaukee, WI).

\section{Photo-crosslinking reaction}

The samples of $100 \mu \mathrm{l}$ containing $30 \mu \mathrm{M}$ calmodulin and 0.1 $\mathrm{mM} \mathrm{Ru}(\mathrm{bpy})_{3} \mathrm{Cl}_{2}$ and $1 \mathrm{mM}$ APS or $0.3 \mathrm{mM} \mathrm{Ru}(\mathrm{bpy})_{3} \mathrm{Cl}_{2}$ and no APS were placed in a $4 \times 4 \mathrm{~mm}$ square quartz cuvette and illuminated for 1 or $5 \mathrm{~min}$, respectively, with blue light at a wavelength of $450 \mathrm{~nm}$, which was selected from an arc lamp
(PTI A1000 model, PTI, Inc., Canada). The light power at the site of the cuvette was $3 \mathrm{~mW} \mathrm{~cm}^{-2}$. The buffer solution contained $1 \mathrm{mM} \mathrm{CaCl} 2,75 \mathrm{mM} \mathrm{KCl}, 5 \mathrm{mM}$ sodium phosphate (pH 7.5). $0.1 \mathrm{mM} \mathrm{Ru}$ (bpy) ${ }_{3} \mathrm{Cl}_{2}$ and $1 \mathrm{mM}$ APS were added just before illumination. After illumination the Ru(II) and APS were removed by passing calmodulin through a Sephadex G-50 spin column. The crosslinking products were analyzed by SDS polyacrylamide electrophoresis. Bands in the gel containing dityrosine were visualized using a CCD camera C5985 (Hamamatsu, Inc., Japan) under UV illumination through a $335 \mathrm{~nm}$ interference filter and emission selection through a $390 \mathrm{~nm}$ cut-off filter. After the fluorescence picture had been taken, the gel was stained with Coomassie Blue.

\section{Fluorescence measurements}

Fluorescence spectra were recorded using a digital phasemodulation spectrofluorimeter ISS K2 (ISS Inc., Champagne, IL). Emission was excited at 270 or $325 \mathrm{~nm}$. The intensity of calmodulin fluorescence, after treatment and purification in a Sephadex G-50 spin column, was corrected for a dilution factor.

\section{Results and discussion}

The main goal of our study is to provide experimental evidence to prove that photo-activated $\mathrm{Ru}(\mathrm{II})$ can induce dityrosine formation in proteins. As a model for the study of dityrosine formation we chose calmodulin, since it has only two tyrosine residues, which could form inter- and intra-molecular crosslinks, as has been demonstrated by other methods. ${ }^{89}$ Dityrosine crosslinking can be monitored by the appearance of specific fluorescence with a maximum at $410 \mathrm{~nm}$ and an excitation maximum at $325 \mathrm{~nm} .{ }^{10-12}$ Any possibility of a contribution from tryptophan residues to the fluorescence can be excluded since calmodulin has no tryptophan residues. The intrinsic fluorescence spectra of calmodulin $\left(\lambda_{\mathrm{ex}}=270 \mathrm{~nm}\right)$ before and after illumination in the presence of $\mathrm{Ru}(\mathrm{II})$ and APS, followed by gel filtration of protein, are presented in Fig. 1.

Calmodulin, excited at $325 \mathrm{~nm}$, did not fluoresce in the range $360-480 \mathrm{~nm}$, whereas after photoreaction with $\mathrm{Ru}(\mathrm{II})$, the typical dityrosine fluorescence appeared (Fig. 2). The presence of APS and $\mathrm{Ru}(\mathrm{II})$ without illumination or illumination of calmodulin alone at $450 \mathrm{~nm}$ wavelength caused no changes in protein fluorescence.

The products of the photoreaction of calmodulin with $\mathrm{Ru}(\mathrm{II})$ were analyzed by SDS polyacrylamide gel electrophoresis. The 


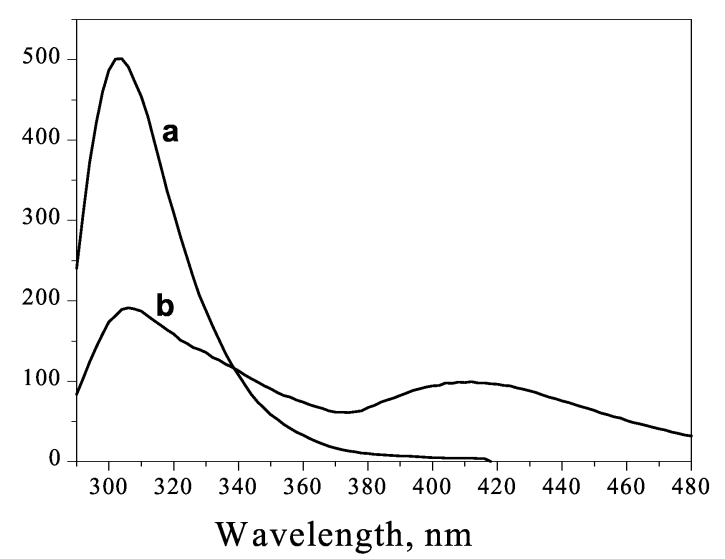

Fig. 1 Steady-state fluorescence spectra of calmodulin before (a) and after (b) exposure for $1 \mathrm{~min}$ to blue light $(450 \mathrm{~nm})$ in the presence of 0.1 $\mathrm{mM} \mathrm{Ru}(\mathrm{II})$ and $1 \mathrm{mM}$ APS followed by gel filtration in a Sephadex G-50 spin column [to remove Ru(II) and APS]. The excitation wavelength was $270 \mathrm{~nm}$.

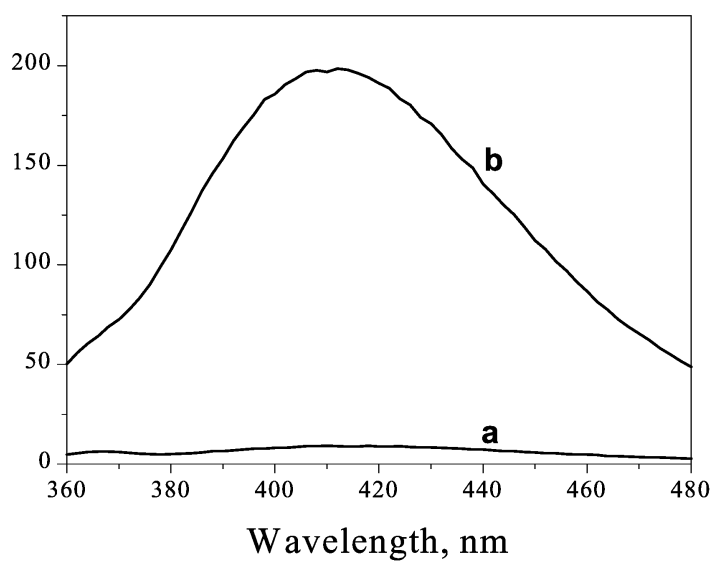

Fig. 2 Steady-state fluorescence spectra of calmodulin before (a) and after (b) exposure for $1 \mathrm{~min}$ to blue light $(450 \mathrm{~nm})$ in the presence of 0.1 $\mathrm{mM} \mathrm{Ru}(\mathrm{II})$ and $1 \mathrm{mM}$ APS followed by gel filtration in a Sephadex G-50 spin column [to remove Ru(II) and APS]. The excitation wavelength was $325 \mathrm{~nm}$.

fluorescence and Coomassie Blue staining images of the same gel are shown in Fig. 3. The untreated calmodulin migrated as a single band with an apparent molecular weight of about $17 \mathrm{kDa}$; however, some minor contamination by S-100 protein was also seen (Fig. 3, A, lane 1). Ru(II), which migrates much faster than calmodulin peptides, was allowed to come out from the gel before electrophoresis was stopped, so that it would not interfere with the dityrosine fluorescence in the gel. The appearance of fluorescence in the monomers, dimers and oligomers after photoreaction with $\mathrm{Ru}(\mathrm{II})$ indicated the occurrence of inter- and intramolecular crosslinking of the tyrosine residues of calmodulin.

APS is known to act as an electron acceptor to generate $\mathrm{Ru}(\mathrm{III})$ from photoexcited $\mathrm{Ru}(\mathrm{II})^{*}{ }^{13,14}$

$$
\mathrm{Ru}(\mathrm{II})^{*}+\mathrm{APS} \rightarrow \mathrm{Ru}(\mathrm{III})+\mathrm{SO}_{4}{ }^{2-}+\mathrm{SO}_{4}{ }^{-\bullet}
$$

The transition from $\mathrm{Ru}(\mathrm{II})$ to $\mathrm{Ru}(\mathrm{III})$ could be easily monitored because it is accompanied by a change in the color of the solution (from orange to green) due to the difference in the absorption spectra of the two compounds. In contrast to $\mathrm{Ru}(\mathrm{II})$ the $\mathrm{Ru}(\mathrm{III})$ is a non-fluorescent compound. To study the possible role of sulfate radicals we carried out the reaction in the presence of $0.5 \%$ ethanol, which is known to act as an efficient quencher of the sulfate radical. ${ }^{15}$ We did not observe any significant differences in the degree of dityrosine fluorescence in
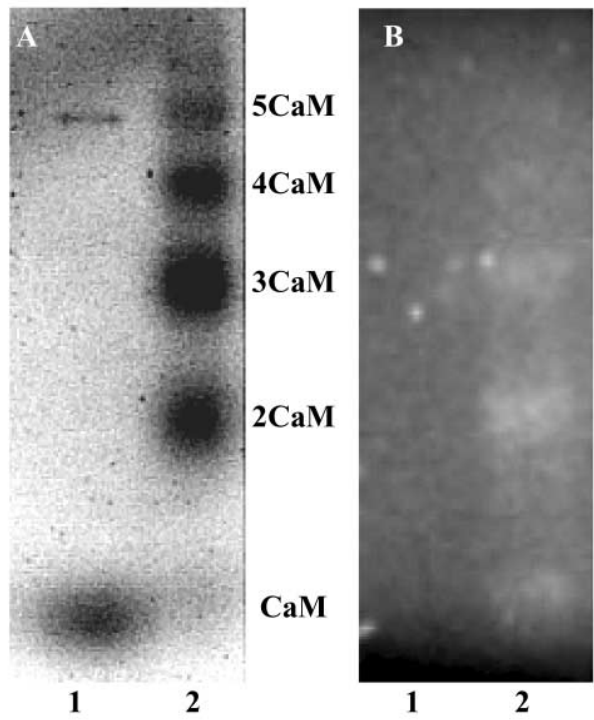

Fig. 3 Coomassie Blue (A) and fluorescence (B) images of the gel. Lanes: 1, calmodulin; 2, calmodulin treated with $\mathrm{Ru}(\mathrm{II})$ and light. Monomers, dimers and higher orders of oligomers are denoted as CaM, 2CaM, 3CaM, etc.

the absence or presence of ethanol (data not shown). Therefore, we concluded that APS serves as a cofactor in the crosslinking reaction, and the sulfate radical does not play a critical role in dityrosine formation.

The formation of dityrosine also occurred in the absence of APS; however, the yield of crosslinking product was low. In the absence of APS, molecular oxygen can play the role of electron acceptor. ${ }^{16-18}$ The quenching of $\mathrm{Ru}(\mathrm{II})^{*}$ by $\mathrm{O}_{2}$ can occur by two mechanisms:

$$
\begin{gathered}
\mathrm{Ru}(\mathrm{II})^{*}+\mathrm{O}_{2} \longrightarrow \mathrm{Ru}(\mathrm{II})+\mathrm{O}_{2}\left({ }^{1} \Delta_{\mathrm{g}}\right) \\
\mathrm{Ru}(\mathrm{II})^{*}+\mathrm{O}_{2} \longrightarrow\left[\mathrm{Ru}(\mathrm{III}) \cdots \mathrm{O}_{2}{ }^{--}\right] \\
{\left[\mathrm{Ru}(\mathrm{III}) \cdots \mathrm{O}_{2}{ }^{\cdot-}\right] \longrightarrow \mathrm{Ru}(\mathrm{III})+\mathrm{O}_{2}{ }^{\cdot-}}
\end{gathered}
$$

The first mechanism [eqn. (2)] is an energy-transfer quenching that generates the ground state $\mathrm{Ru}(\mathrm{II})$ and singlet oxygen. The second one involves charge transfer to form a cage complex $\left[\mathrm{Ru}(\mathrm{III}) \mathrm{CO}_{2} \mathrm{O}^{-{ }^{-}}\right]$in the first stage [eqn. (3a)] and then formation of $\mathrm{Ru}(\mathrm{III})$ and the superoxide radical anion [eqn. (3b)]. In as much as $\mathrm{O}_{2}\left({ }^{1} \Delta_{\mathrm{g}}\right)$ lies $0.98 \mathrm{eV}$ above the triplet ground state, and the $0-0$ transition energy of the $\mathrm{Ru}(\mathrm{bpy})_{3}$ is $2.15 \mathrm{eV}$, it is thermodynamically possible for $\mathrm{Ru}(\mathrm{II})$ to react with $\mathrm{O}_{2}$ and generate $\mathrm{O}_{2}\left({ }^{1} \Delta_{\mathrm{g}}\right)$ by reaction (2). ${ }^{17}$ On the other hand, the value of $E^{\circ}\left(\mathrm{O}_{2} / \mathrm{O}_{2}{ }^{-}\right)$is $-0.16 \mathrm{~V}$ (in aqueous solution), whereas the value of $E^{\circ}\left[\mathrm{Ru}(\mathrm{III}) / \mathrm{Ru}(\mathrm{II})^{*}\right]$ is $-0.88 \mathrm{~V}$, therefore the pathway represented by eqns. (3a) and (3b) is also thermodynamically possible. ${ }^{17}$ Previously it was shown that neither singlet oxygen nor the superoxide radical is involved in the formation of dityrosine. ${ }^{19}$ To verify this we investigated the effect on dityrosine formation of sodium azide $\left(\mathrm{NaN}_{3}\right)$ and superoxide dismutase (SOD), which are known to be good scavengers of singlet oxygen and superoxide, respectively. We found no effect of $\mathrm{NaN}_{3}$ or SOD on the formation of dityrosine in the presence of APS (Fig. 4), it follows that reaction (1) is the predominant one under these conditions. In the absence of APS the SOD increased production of dityrosine by $20 \%$, while $\mathrm{NaN}_{3}$ had no effect on the reaction (Fig. 4). The enhancement of dityrosine production by SOD could be explained by a decrease in the of rate of recombination of superoxide with $\mathrm{Ru}(\mathrm{III})$ and transformation of $\mathrm{Ru}(\mathrm{III})$ to $\mathrm{Ru}(\mathrm{II})$ and superoxide to $\mathrm{O}_{2}$. SOD increases the $\mathrm{Ru}$ (III) concentration and therefore accelerates the dityrosine production. $\mathrm{Ru}(\mathrm{III})$ is a strong oxidant capable of 

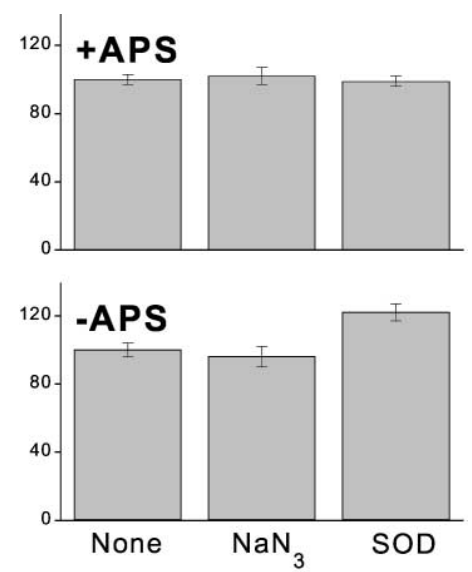

Fig. 4 Effect of additives (1 $\mathrm{mM} \mathrm{NaN}_{3}$ and $1.5 \mu \mathrm{M}$ SOD) on the $\mathrm{Ru}(\mathrm{II}) /$ light-mediated formation of dityrosine crosslinks in calmodulin. The numbers on the axes represent percent of area under the spectrum of dityrosine fluorescence relative to that in the absence of $\mathrm{NaN}_{3}$ and SOD.

oxidizing amino acids, including tyrosine residues. The formation of tyrosine radicals is followed by dityrosine crosslinking.

We have shown for the first time that $\mathrm{Ru}(\mathrm{II})$ can induce dityrosine formation in proteins upon blue-light illumination. The results presented provide insights into the mechanism of photooxidation of proteins by ruthenium compounds. The ability of ruthenium compounds under light illumination to oxidize tyrosine residues and induce dityrosine crosslinking of calmodulin might have a practical application in the inhibition of calmodulin-mediated signal transduction in cancer cells. Our preliminary data indicated that, upon light illumination, $\mathrm{Ru}(\mathrm{II})$ can inhibit the activity of the matrix metalloproteinases, which have tyrosine residues in the active site. ${ }^{20}$ We have also demonstrated the feasibility of the detection of protein dityrosine crosslinks directly in the polyacrylamide gel by fluorescence methods.

\section{Acknowledgements}

This work has been supported in part by UNTHSC, Institute for Cancer Research and Bank One.

\section{References}

1 E. Borgarello, J. Kiwi, E. Pelizzetti, M. Visca and M. Grätzel, Photochemical cleavage of water by photocatalysis, Nature, 1981, 289, $158-160$.

2 L. Dong and M. T. Martin, Enzyme-triggered formation of electrochemiluminescent ruthenium complexes, Anal. Biochem., 1996, 236, 344-347.

3 M. Carballo, R. Vilaplana, G. Márquez, M. Conde, J. Bedoya, F. González-Víchez and F. Sobrino, A newly synthesized molecule derived from ruthenium cation, with antitumour activity, activates
NADPH oxidase in human neutrophils, Biochem. J., 1997, 328, 559-564.

4 E. Terpetschnig, H. Szmacinski and J. R. Lakowicz, Long-lifetime metal-ligand complexes as probes in biophysics and clinical chemistry, Methods Enzymol., 1997, 278, 295-321.

5 W. A. Prutz, J. Balter and E. J. Land, Phenol coupling initiated by one-electron oxidation of tyrosine units in peptides and histone, Int. J. Radiat. Biol., 1983, 44, 183-196.

6 D. A. Fancy and T. Kodadek, Chemistry for the analysis of proteinprotein interactions: rapid and efficient cross-linking triggered by long wavelength light, Proc. Natl. Acad. Sci. U. S. A., 1999, 96, 6020-6024

7 D. A. Fancy, C. Denison, K. Kim, Y. Xie, T. Holdeman, F. Amini and T. Kodadek, Scope, limitations and mechanistic aspects of the photo-induced cross-linking of proteins by water-soluble metal complexes, Chem. Biol., 2000, 7, 697-708.

8 D. A. Malencik and S. R. Anderson, Dityrosine formation in calmodulin, Biochemistry, 1987, 26, 695-704.

9 D. A. Malencik and S. R. Anderson, Dityrosine formation in calmodulin: conditions for intermolecular cross-linking, Biochemistry, 1994, 33, 13363-13372.

10 R. Aeschbach, R. Amadò and H. Neukom, Formation of dityrosine cross-links in proteins by oxidation of tyrosine residues, Biochim. Biophys. Acta, 1976, 439, 292-301.

11 D. A. Malencik and S. R. Anderson, Fluorometric characterization of dityrosine: complex formation with boric acid and borate ion, Biochem. Biophys. Res. Commun., 1996, 178, 60-67.

12 D. A. Malencik, J. F. Sprouse, C. A. Swanson and S. R. Anderson, Dityrosine: preparation, isolation, and analysis, Anal. Biochem., 1996, 242, 202-213.

13 U. Nickel, Y.-H. Chen, S. Schneider, M. I. Silva, H. D. Burrows and S. J. Forosinho, Mechanism and kinetics of the photocatalyzed oxidation of $p$-phenylenediamines by peroxydisulfate in the presence of tris-2,2'-bipyridylruthenium(II), J. Phys. Chem., 1994, 98, 2883-2888.

14 A. Aboul-Enein and D. Schulte-Frohlinde, Biological deactivation and single-strand breakage of plasmid DNA by photosensitization using tris(2, 2'-bipyridyl)ruthenium(II) and peroxydisulfate, Photochem. Photobiol., 1988, 48, 27-34.

15 J. G. Muller, P. Zheng, S. E. Rokita and C. J. Burrows, DNA and RNA modification promoted by $\left[\mathrm{Co}\left(\mathrm{H}_{2} \mathrm{O}\right)_{6}\right] \mathrm{Cl}_{2}$ and $\mathrm{KHSO}_{5}$ : Guanine selectivity, temperature dependence, and mechanism, J. Am. Chem. Soc., 1996, 118, 2320-2325.

16 J. N. Demas, D. Diemente and E. W. Harris, Oxygen quenching of charge-transfer excited states of ruthenium(II) complexes. Evidence for singlet oxygen production, J. Am. Chem. Soc., 1973, 95, 6864 6865.

17 Q. G. Mulazzani, H. Sun, M. Z. Hoffman, W. E. Ford and M. A. J. Rogers, Quenching of the excited state of ruthenium(II)-diimine complexes by oxygen, J. Phys. Chem., 1994, 98, 1145-1150.

18 X. Zhang and M. A. J. Rodgers, Energy and electron transfer reactions of the MLCT state of ruthenium tris(bipyridyl) with molecular oxygen: A laser flash photolysis study, J. Phys. Chem., 1995, 99, 12797-12803.

19 J. D. Spikes, H.-R. Shen, P. Kopeckova and J. Kopecek, Photodynamic crosslinking of proteins. III. Kinetics of the FMNand rose negal-sensitized photooxidation and intermolecular crosslinking of model tyrosine-containing $N$-(2-hydroxypropyl)methacrylamide copolymers, Photochem. Photobiol., 1999, 70, $130-137$.

20 Ya. K. Reshetnyak, O. A. Andreev and R. H. Goldfarb, Photoactivatable inhibitors of matrix metalloproteinases, Proc. Am. Assoc. Cancer Res., 2001, 5082, 945-94. 